OPEN ACCESS

Citation: Shaimaa S. Sobieh, Dina M. Fahmy (2021) Assessment of antimitotic and programmed cell death stimulation potentials of Galium sinaicum (Delile ex Decne) Boiss. at the cellular level. Caryologia 74(2): 21-35. doi: 10.36253/ caryologia-1057

Received: August 21, 2020

Accepted: July 20, 2021

Published: October 08, 2021

Copyright: (c) 2021 Shaimaa S. Sobieh, Dina M. Fahmy. This is an open access, peer-reviewed article published by Firenze University Press (http://www.fupress.com/caryologia) and distributed under the terms of the Creative Commons Attribution License, which permits unrestricted use, distribution, and reproduction in any medium, provided the original author and source are credited.

Data Availability Statement: All relevant data are within the paper and its Supporting Information files.

Competing Interests: The Author(s) declare(s) no conflict of interest.

ORCID

SSS: $0000-0002-1286-7352$

\section{Assessment of antimitotic and programmed cell death stimulation potentials of Galium sinaicum (Delile ex Decne) Boiss. at the cellular level}

\author{
ShaimaA S. SobIeh ${ }^{1, *}$, Dina M. Fahmy ${ }^{2}$ \\ ${ }^{1}$ Botany Department, Faculty of Women for Art, Science and Education, Ain Shams Uni- \\ versity, Cairo, Egypt \\ ${ }^{2}$ Natural Product Unit, Medicinal and Aromatic Plant Department, Desert Research \\ Center, Cairo, Egypt \\ * Corresponding author. E-mail: shimaa.sobieh@women.asu.edu.eg,
}

\begin{abstract}
Galium sinaicum is a wild medicinal plant in saint Catherine, Egypt. To distinguish apoptotic effect of G. sinaicum ethanol extract (GsEE). The role of GsEE in inducing programmed cell death (PCD) of Allium cepa root meristematic cell(AcR) was examined. Cells was subjected to GsEE in definite concentrations $(0.1,0.3,0.5 \%)$ and duration $(6,12 \mathrm{~h})$, then PCD induction was assessed. Application of GsEE arrested the mitotic division of AcR with metaphase accumulation. Electron microscopy analysis demonstrated ultrastructural alterations of organelles verifying PCD hallmarks. Protein electrophoresis analysis of AcR revealed a change in protein profile of Allium cepa root, also quantitative analysis showed significant increase in nuclease activity enzymes that stimulated DNA laddering fragmentation. Additionally, cell proliferation of MCF7 and BHK21 was arrested by GsEE. Apoptotic effect of G. sinaicum may be attributed to the presence of potent phenolic compounds such as querectin and rutin as established by HPLC phenolic fingerprint analysis.
\end{abstract}

Keywords: Galium sinaicum, programmed cell death (PDC) hallmarks, Allium cepa,
MCF-7, BHK21, HPLC.

Keywords: Galium sinaicum, programmed cell death (PDC) hallmarks, Allium cepa,
MCF-7, BHK21, HPLC.

\title{
INTRODUCTION
}

When conventional medicine reaches an edge of success, patients search for alternatives. Traditional phyto-medicine gains more and more consideration, especially with respect to alternative treatment of cancer. An intensive survey of plants especially which have an appropriate history of cancer treatment in folklore began in the later 1950s mainly since the National Cancer Institute (NCI) adopted random selection screening program, as novel compounds may be found anywhere from plant kingdom.

About $60 \%$ of currently used anticancer agents are derived from natural sources (Newman et al. 2002; Cragg et al. 2005). Therefore, many researchers investigate extensively the mechanism of interaction between phytochemicals and cancer cells (Kaufman et al. 1999; Amirghofran et al. 2006a). 
Phytochemicals may modulate cell signalling pathways thereby inhibiting cancer development or progression and induce apoptosis in malignant cells (Stevenson and Hurst 2007).

Apoptosis is a programmed cell death and a highly organized physiological mechanism to destroy injured or abnormal cells. Apoptotic cells manifest morphological features and characteristic molecular expression. Provoking apoptosis in cancer cell is recognized as an efficient strategy for cancer therapy. Apoptosis also seems to be a dependable marker for the evaluation of potential agents for cancer inhibition (Taraphdar et al. 2001).

In past decades, research on traditionally tumour inhibitory medicinal plants have yielded an impressive array of novel healing plants via authorizing their apoptosis mechanism (Taraphdar et al. 2001).Epidemiological studies suggest that consumption of diets containing fruits and vegetables, which are major sources of phytochemicals and micronutrients, may reduce the risk of developing cancer (Reddy et al. 1997). Developed studies with such plants with respect to their abilities to induce apoptosis and figure out their mechanism of action may provide a good aim of work and valuable information for their possible application in cancer therapy or prevention.

Thus, considering the importance of screening apoptotic inducers from plants, Galium sinaicum was elected to be screened for its apoptotic enhancement activity. Galium sinaicum (Delile ex Decne) Boiss. is a wild herbal plant habituated in Saint Catherine protectorate, South Saini, Egypt. G. sinaicum belongs to Rubiaceae characterized by presence of anthraquinones and lignens in root, and flavonoids in aerial part (El-Gamal et al. 1999) like other Galium sp.for instance G. Verum and G. Mollugo and G. spurium, G. aparine G. odoratum (Yang et al. 2011, Vlase et al. 2014, Bradic et al. 2018) In folk medicine Galium species are used to coagulate milk, also as diuretics, choleretics, against diarrhea and in the treatment of some stomach complaints, gout, epilepsy and as anticancer remedy in Europe, Africa and Australia (Güvenalp et al. 2006a; Güvenalp et al. 2006b; Gîrd et al. 2015). Additionally, in Pakistan, G. aparine is used as herbal cure for cancer disease (Tariq et al. (2017).

No data have been previously stated on G. sinaicum regarding its phenolic content and its potential as antiproliferative and apoptotic inducing agent. Thus, phytochemical components and potential antiproliferative activity on breast cancer (MCF-7) and normal kidney cell of baby hamster (BHK21) cell line as well as meristematic cell of root of Allium cepa L. of G. sinaicum were investigated.

\section{MATERIALS AND METHODS}

Herbal material: Aerial part of Galium sinaicum (Delile ex Decne) Boiss. was collected in Spring from Wadi Gemal - Saint Katherine protectorate, South SainiEgypt. It was identified and authenticated by Saint Katherine Protectorate members. Arial parts of Galium sinaicum were collected, packed in paper bags and coded in the field. The aerial parts of the plant materials were airdried at room temperature and grinded to coarse powder.

\section{Tested models}

Cell lines: Breast adenocarcinoma cell line (MCF$7\left(\right.$ ATCC $\left.^{\bullet} \mathrm{HTB}^{\mathrm{mm}}\right)$ ) and normal baby hamster kidney fibroblasts cell line (BHK 21[C-13] (ATCC ${ }^{\otimes}$ CCL10 $\left.^{\text {mit}}\right)$ ) were used in this study. Cell lines were obtained from the American Type Culture Collection (ATCC, Minnesota, U.S.A.). The cell lines were maintained at the National Cancer Institute, Cairo, Egypt, by serial subculturing.

Onions bulbs: Root tips of Allium cepa L. $(2 n=$ 16 , variety Giza 20) (AcR) were obtained from Desert Research Center, Cairo, Egypt.

\section{Preparation of extract}

A weight of $200 \mathrm{gm}$ of powdered plant was extracted by maceration technique in ethanol: water $(8: 2)$ $(200 \mathrm{ml} \times 4)$. Extract was filtered, concentrated under reduced pressure using rotary evaporator (Buchi, R200, Switzerland) at $40^{\circ} \mathrm{C}$. The dry extract (GsEE) stored at $4^{\circ} \mathrm{C}$ for further investigation (Harborne 1973).

\section{Measurement of programmed cell death (PCD)}

As stated before, PCD involves cell with changes only after the point of no return. There are several techniques to obtain information about cell death and induction of PCD such as measurement of mitotic indices, morphological changes, and DNA profile etc.

\section{Evaluation of antiproliferation activity}

Sulphorhodamine-B (SRB) assay was performed to assess anti-proliferative potency of GsEE as reported by Vichai and Kirtikara (2006). MCF-7 and BHK21 cells were planted in 96-well microtiter plates at initial concentration of $3 \times 10^{3}$ cell/well in a $150 \mu$ RPMI 1640 and left for $24 \mathrm{~h}$ to attach to the plates. GsEE were prepared 
from the stock solutions by serial dilution $(0,12.5,25,50$ \& $100 \mu \mathrm{g} / \mathrm{ml}$ ) in DMSO to give a volume of $100 \mu \mathrm{l}$ in each well. The assay for both cell lines was completed in triplicates and the culture plates were kept at $37^{\circ} \mathrm{C}$ with $5 \%$ $\mathrm{CO} 2$ for $48 \mathrm{~h}$. After $48 \mathrm{~h}$ of incubation, the cells were fixed with $50 \mu 110 \%$ cold trichloroacetic acid for $1 \mathrm{~h}$ at $4^{0} \mathrm{C}$. The plates were washed with distilled water using automatic washer (Tecan, Germany) and stained with $50 \mu \mathrm{l} 0.4 \%$ SRB dissolved in $1 \%$ acetic acid for 30 minutes at room temperature. Subsequently, the plates were washed with $1 \%$ acetic acid and air-dried. The dye was solubilized with $100 \mu \mathrm{l} /$ well of $10 \mathrm{M}$ tris base ( $\mathrm{pH} 10.5)$. Absorbance value was measured spectrophotometrically at $570 \mathrm{~nm}$ with a microplate reader (Sunrise Tecan reader, Germany). Cell survival was measured as the percentage absorbance compared to the control (non-treated cell). The $\mathrm{IC}_{50}$ values were calculated by GraphPad Prism 5 software (GraphPad Software Inc., San Diego, CA).

\section{Mitotic analysis using A. cepa root}

Five A. cepa bulbs were used for each concentration. A. серa bulbs were germinated in distilled water at room temperature. When the roots reached $3-4 \mathrm{~cm}$, they were treated with $0.1,0.3$ and $0.5 \%$ of GsEE for 6 and $12 \mathrm{~h}$, then the roots were fixed in Carnoy's fixative (ethyl alcohol: glacial acetic acid 3:1 (v/v)). For the untreated group, A. серa bulbs were germinated in distilled water. The roots were taken out of Carnoy's fixative after $24 \mathrm{~h}$, hydrolyzed with $1 \mathrm{~N} \mathrm{HCl}$ at $60^{\circ} \mathrm{C}$ for $5 \mathrm{~min}$, washed with distilled water and stained using Schiff's stain for $1 \mathrm{~h}$ in the dark. Preparations were carried out using Feulgen's squash technique. Slides were examined at 400x magnification. The number of cells in the mitotic division was scored and the mitotic index (MI) was calculated according to Fiskesjö (1997). Mitotic phase indices were also determined. The cytological abnormalities were scored in the mitotic cells. The most common abnormalities were photographed. Statistical analysis was carried out using GraphPad (Version 4.0; San Diego, USA, www. graphpad.com) with five replicates for each group. The significance was analysed using Tukey's and Dunnett's tests (significance was accepted at $p \leq 0.05$ and $p \leq 0.01$ ). Data were expressed as mean \pm standard deviation (SD).

\section{Electron microscopy investigation}

Transmission electron microscopy is the method of choice when making detailed examination of the structural changes within cells. Ultrastructural changes such as chromatin condensation and appearance of vacu- oles containing remnants of cell organelles. AcR tips (not more than $1 \mathrm{~mm}$ ) of control and treated groups were fixed in $2 \%$ glutaraldehyde in $0.05 \mathrm{~mol} / 1$ sodium cacodylate buffer $(\mathrm{pH} 6.9)$ for $2 \mathrm{~h}$ at $4^{\circ} \mathrm{C}$. The tissue was rinsed in sodium cacodylate buffer and postfixed in $4 \%$ osmium tetraoxide for 1 hour at $4^{\circ} \mathrm{C}$. The tissue was rinsed in sodium cacodylate buffer and dehydrated in graded ethanol water series. Following passage through a graded propylene oxide/ethanol series, the root tips were gradually infiltrated with resin by placing them for $24 \mathrm{~h}$ in each of series of resin/propylene oxide mixtures, followed by three changes in 100\% Epon 812 . Then materials were embedded in freshly prepared resin mixture and polymerized in oven at $60^{\circ} \mathrm{C}$ for $48 \mathrm{~h}$ (Glińska and Gabara 2000). Sections $(1 \mu \mathrm{m})$ were cut with Reichert Ultra-microtome, mounted on copper grids and stained with $0.5 \%$ uranyl acetate for $30 \mathrm{~min}$ and lead citrate for 30min as described by Reynolds (1963). Observations were carried out using JEOL TEM 1010 transmission electron microscope at $80 \mathrm{kV}$, Electron Microscope Unit, Center for Mycology and The Regional Biotechnology, Al Azhar University, Cairo, Egypt.

\section{Measurement of the endonuclease activity}

Nuclease activity was determined by the release of acid soluble nucleotides from single-stranded (ss) or double strand (ds) calf thymus DNA, following the method of Blank and McKeon (1989). A weight of $3 \mathrm{~g}$ of AcR samples was ground in liquid nitrogen with a mortar and pestle. Ice-cold buffer $(0.05 \mathrm{M}$ Tris- $\mathrm{HCl}, \mathrm{pH}$ 7.5/0.15M NaCl/1 mM N-ethylmaleimide; $10 \mathrm{ml} / \mathrm{g}$ of leaf) was added and the suspensions were homogenized in an ice bath for $1 \mathrm{~min}$. Aliquots of homogenates were centrifuged for $10 \mathrm{~min}$ at $6000 \mathrm{rpm}$ in an Eppendorf microcentrifuge at $6^{\circ} \mathrm{C}$. The supernatant solutions were frozen and stored at $-70^{\circ} \mathrm{C}$. Double-stranded calf thymus DNA (Sigma) was dissolved $(1 \mathrm{mg} / \mathrm{ml})$ in sterile distilled water, boiled for $10 \mathrm{~min}$ and placed on ice immediately. Assay mixtures containing DNA calf thymus, reaction buffer $\left(0.2 \mathrm{M} \mathrm{NaCl}, 0.002 \mathrm{M} \mathrm{ZnCl}_{2}, 0.06 \mathrm{M} \mathrm{CH}_{3} \mathrm{COONa}\right.$, $\mathrm{pH}(4.6))$ and $0.1 \mathrm{ml}$ cytosolic homogenate were incubated for 10 in at $37^{\circ} \mathrm{C}$. the reactions were stopped by the addition of $2 \mathrm{ml}$ of $15 \%$ perchloric acid on ice for $10 \mathrm{~min}$, then centrifuged for $15 \mathrm{~min}$ at $2000 \mathrm{rpm}$. The absorbency was recorded at $260 \mathrm{~nm}$. Native calf thymus DNA solution without sample homogenate was used as blank

units $/ \mathrm{ml}=\left(\left(\mathrm{A}_{\mathrm{s}}-\mathrm{A}_{\mathrm{b}}\right) \times\right.$ dilution $\left.\times 1242\right) / 10$

One unit is the amount of enzyme liberating $1 \mu \mathrm{g}$ (0.033 A260) of acid-soluble nucleotides from heat-dena- 
tured DNA per minute at $37^{\circ} \mathrm{C}$ and at $\mathrm{pH}$ 4.6. Where 1242 is a factor derived by dividing the reaction volume, by the $A_{260}$ of $1 \mu \mathrm{g}$, which is 0.033 , and dividing by $0.1 \mathrm{ml}$ (volume of enzyme sample used).

\section{Detection of DNA fragmentation}

To examine DNA fragmentation as a marker of programmed cell death, DNA was extracted by CTAB reagent from AcR cells treated with GsEE and untreated cells by the method of Doyle and Doyle (1987). AcR cells $(0.5 \mathrm{~g})$ were frozen in liquid nitrogen and ground into a fine powder. Each sample was incubated for $60 \mathrm{~min}$ at $65^{\circ} \mathrm{C}$ in $9 \mathrm{ml}$ pre-warmed $\mathrm{CTAB}$ extraction buffer, then mixed with an equal volume of chloroform-isoamyl alcohol (24:1). After gently shaking for $5 \mathrm{~min}$, the mixture was centrifuged for $15 \mathrm{~min}$ at $10000 \mathrm{rpm}$. The chloroform-isoamyl alcohol extraction was repeated when necessary. DNA was recovered by centrifugation for $10 \mathrm{~min}$ at $10000 \mathrm{rpm}$, followed by washing with $70 \%$ ethanol, and dissolved in $1 \mathrm{ml}$ TE buffer. To detect DNA fragmentation, samples were run on a $1 \%(\mathrm{wt} / \mathrm{vol})$ agarose gel and stained with $0.5 \mu \mathrm{g}$ of ethidium bromide per $\mathrm{ml}$ (Tada et al. 2001). The bands were visualized under UV transilluminator then were photographed for further analysis using Gene Tools syngene ver. 4.00(a) gel documentation system software.

\section{Protein electrophoresis of A. cepa root}

Distribution of protein pattern was detected using continuous polyacrylamide gel electrophoresis (SDSPAGE) using Hoefer (SE 245) dual vertical mini-gel. A weight of $1 \mathrm{~g}$ of each treatment was extracted with $1 \mathrm{ml}$ of extraction buffer contained $1.21 \mathrm{~g}$ tris $\mathrm{HCl}, 1 \mathrm{ml} 10 \%$ SDS, $0.5 \mathrm{ml} \beta$-mercaptoethanol and $5 \mathrm{~g}$ sucrose completed to $50 \mathrm{ml}$ distilled water $(\mathrm{pH} 8.0)$. Protein pellets were precipitated by cooling centrifuge at $4000 \mathrm{rpm}$ for 15 min., pellets were dissolved with $0.5 \mu \mathrm{l}$ sample buffer contained $1.2 \mathrm{ml}$ tris $\mathrm{HCl}, 2 \mathrm{ml} 10 \%$ SDS, $1 \mathrm{ml}$ glycerol, $0.5 \mathrm{ml} 0.4 \%$ bromophenol, $0.5 \mathrm{ml} \beta$-mercaptoethanol, $4.8 \mathrm{ml}$ distilled water. The homogenate was boiled in water bath for 90 seconds, loaded on gel. Bio Rad low molecular weight protein marker (97 to $14.4 \mathrm{KDa}$, Catlog number 1610304) was loaded on gel as protein standard. The gel was forced to run at 70 volts, $40 \mathrm{~mA}$. Finally, gel was stained with Coomassie Brilliant Blue G-250 stain and destained according to Laemmli (1970). Gel was photographed and scanned for further documentation system using Gel Pro Analyzer version 3.1 for windows95-NT (Media Cybernetics 1993-1997).
High performance liquid chromatography (HPLC)fingerprint

The instrumentation used for HPLC analysis consisted of Agilent 1260 series. Chromatographic column was used: Eclipse Plus C18 column $(4.6 \mathrm{~mm}$ x $250 \mathrm{~mm}$ i.d., $5 \mu \mathrm{m}$ ). Mobile phase flow rate was set by $1.0 \mathrm{ml} \mathrm{min}^{-}$ ${ }^{1}$; sample volume was $10 \mu \mathrm{l}$. The mobile phase consisted of water (A) and $0.02 \%$ tri-floro-acetic acid in acetonitrile (B). The mobile phase was programmed consecutively in a linear gradient as follows: 0 min $(80 \% \mathrm{~A}) ; 0-5 \min (80 \%$ A); $5-8 \min (40 \% \mathrm{~A}) ; 8-12 \min (50 \% \mathrm{~A}) ; 12-14 \min (80 \%$ A) and $14-16 \mathrm{~min}(80 \% \mathrm{~A})$. monitoring the UV spectrum of the peaks was done by ultraviolet detector at $280 \mathrm{~nm}$. Phenolic compounds were identified by comparing their relative retention times with those of the standards mixture chromatogram. The concentration of an individual compound was calculated based on peak area measurements, then converted to mg phenolic $\mathrm{g}^{-1}$ dry weight. All chemicals and solvents used were HPLC spectral grade.

\section{RESULTS}

\section{Extraction yield}

About $200 \mathrm{~g}$ of dry powder of aerial parts of G. sinaicum was macerated by $80 \%$ ethanol. The percentage yield of the crude extract used for the assays was $13 \mathrm{~g} \%$.

\section{Effect of GsEE on the viability of MCF-7 and BHK21}

Cell viability percentage was assessed by SRB assay after $48 \mathrm{~h}$. of incubation. GsEE decreased cell viability in a concentration-dependent manner in both MCF-7 and BHK21 as compared to untreated controls (Fig. 1). IC $_{50}$ value of GsEE was $35 \mu \mathrm{g} / \mathrm{ml}$ and $39.5 \mu \mathrm{g} / \mathrm{ml}$ against MCF7 and BHK21, respectively (Table 1)

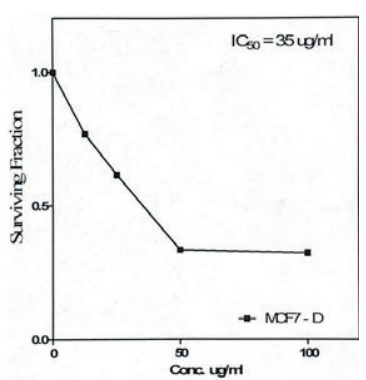

(a)

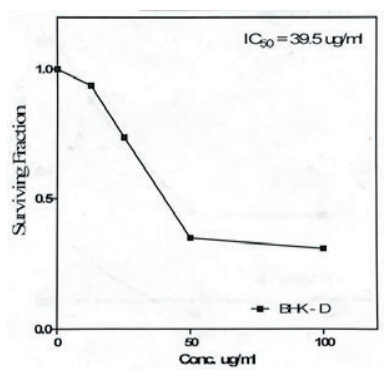

(b)
Figure 1. Antiproliferative effect of GsEE (0-100 $\mu \mathrm{g} / \mathrm{ml})$ using SRB method on (a) and MCF-7 (b) BHK21 cell lines. 
Table 1. $\mathrm{IC}_{50}$ of antiproliferative activity of $\mathrm{GsEE}(\mathrm{n}=3)$.

AntiproAntiproliferative activity on MCF-7, $\mathrm{IC}_{50}(\mu \mathrm{g} / \mathrm{ml}$ of extract)

AntiproAntiproliferative activity on $\mathrm{BHK}_{2} 1, \mathrm{IC}_{50}(\mu \mathrm{g} / \mathrm{ml}$ of extract)

Mitotic analysis using $A$. cepa root

A remarkable decrease in the mitotic indices of AcR cells was clearly found after the application of GsEE. This remarkable decrease was dose and time dependent (Table 2). Treatment with GsEE has stopped the progress through mitosis of many cells and they began to accumulate in mitosis. Concentration of $0.5 \%$ of GsEE exerted the most potent effect on the mitotic index; it decreased the mitotic index to the minimum proportion (0.92) after $6 \mathrm{~h}$ exposure, while the maximum proportion of mitotic index (2.08) was achieved after exposure to $0.1 \%$ of GsEE for $6 \mathrm{~h}$. Concentration $0.5 \%$ of GsEE caused the complete arrest of the mitotic process after $12 \mathrm{~h}$ of treatment. The statistical analysis of the data revealed that all doses of GsEE induced a highly significant reduction in mitotic index of AcR cells as compared with their control (Table 2).

The obvious accumulation in metaphase stage was noted after treatment with all concentrations of GsEE, this accumulation was on the expense of prophase and anaphase stages (Table 2). As well, treatment of AcR cells with GsEE resulted in a high increase in the total percentage of abnormalities exceeded its counterpart control, this increase was concentration and time depend- ent (Table 2). The spindle apparatus was the target of the treatment as can be demonstrated by the induction of spindle disturbance as a common type of aberrations. Spindle disturbance included several forms of spindle disturbance like disturbed metaphase, disturbed anaphase and diagonal configuration. Stickiness was also detected during the study (Fig. 2).

\section{Electron microscopy}

Induction of PCD in AcR treated with GsEE was followed up by transmission electron microscope. Root tip cells of control possessed a large-rounded nucleus with intact nuclear membrane, dense cytoplasm and wellorganized organelles (Fig. 3a). The electron micrographs after treatment with GsEE showed changes in sub-cellular organelles and induction of some PCD hallmarks. Fig. $3 \mathrm{~b}$ revealed the early stage of PCD as confirmed by the formation of dilated endoplasmic reticulum, intensification in the vacuolar system and presence of organelles with intact membrane inside the vacuole. The next stage of PCD was illustrated by the most striking aspects of PCD where obvious disintegration of nuclear membrane and formation of clotting chromatin was observed (Figs. 3c, d). The result of prolonged immersion of AcR in the highest concentration (0.5\%) of GsEE showed the final stage of PCD in which the vacuolar system extremely expanded, the shrinkage nucleus and undifferentiated organelles with intact membranes were observed only around the periphery of the cell (Fig 3e).

Table 2. Mitotic and phase indices and percentage of mitotic abnormalities of AcR cells treated with GsEE.

\begin{tabular}{|c|c|c|c|c|c|}
\hline Treatment & Mitotic index \pm SD & Mitotic abnormalities & Prophase & Metaphase & Ana-telophase \\
\hline \multicolumn{6}{|l|}{ Control } \\
\hline $6 \mathrm{hrs}$ & $3.26 \pm 0.70$ & $5.32 \pm 0.15$ & $32.45 \pm 0.31$ & $34.30 \pm 0.19$ & $33.25 \pm 0.15$ \\
\hline $12 \mathrm{hrs}$ & $3.83 \pm 0.23$ & $5.89 \pm 0.39$ & $32.10 \pm 0.57$ & $35.66 \pm 0.66$ & $32.24 \pm 0.70$ \\
\hline \multicolumn{6}{|l|}{$0.1 \%$} \\
\hline $6 \mathrm{hrs}$ & $2.08^{*} \pm 0.19$ & $15.33^{* *} \pm 0.07$ & $24.62^{*} \pm 0.82$ & $48.31^{* *} \pm 25$ & $27.07^{*} \pm 0.38$ \\
\hline $12 \mathrm{hrs}$ & $1.93^{* *} \pm 0.08$ & $23.04^{* *} \pm 0.96$ & $20.32^{* *} \pm 0.41$ & $51.11^{* *} \pm 0.10$ & $28.57^{*} \pm 0.70$ \\
\hline \multicolumn{6}{|l|}{$0.3 \%$} \\
\hline $6 \mathrm{hrs}$ & $1.56^{* *} \pm 0.73$ & $25.98^{* *} \pm 0.67$ & $27.25^{*} \pm 0.13$ & $50.91^{* *} \pm 0.09$ & $21.84^{* *} \pm 0.23$ \\
\hline $12 \mathrm{hrs}$ & $0.93^{* *} \pm 0.24$ & $29.12^{* *} \pm 0.53$ & $23.03^{*} \pm 0.68$ & $59.43^{* *} \pm 0.70$ & $17.54^{* *} \pm 0.70$ \\
\hline \multicolumn{6}{|l|}{$0.5 \%$} \\
\hline $6 \mathrm{hrs}$ & $0.92^{* *} \pm 0.36$ & $34.57^{* *} \pm 0.21$ & $23.96^{*} \pm 0.74$ & $59.98^{* *} \pm 0.37$ & $16.06^{* *} \pm 0.49$ \\
\hline $12 \mathrm{hrs}$ & $0.00 \pm 0.00$ & $00.00 \pm 0.00$ & $00.00 \pm 0.00$ & $00.00 \pm 0.00$ & $00.00 \pm 0.00$ \\
\hline
\end{tabular}

${ }^{*}$ Statistically significant at $P \leq 0.05$

${ }^{*}$ Statistically significant at $P \leq 0.01$ 


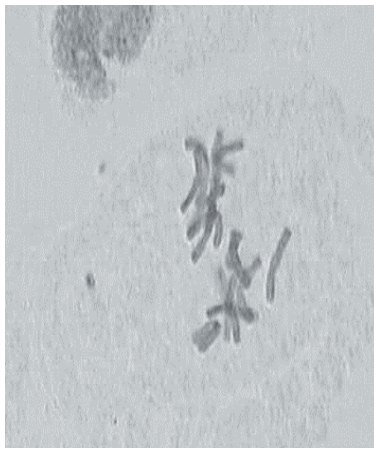

(a)

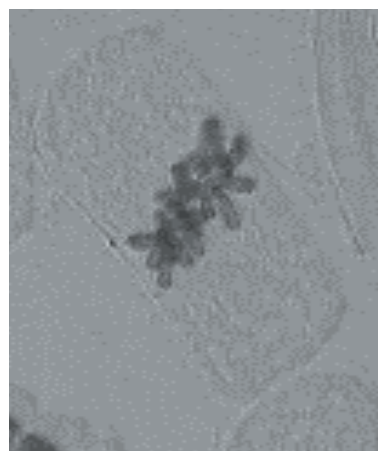

(e )

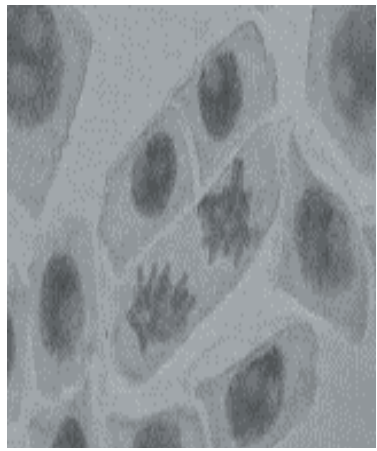

(i)

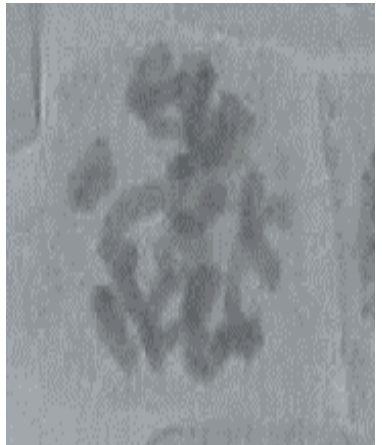

(b)

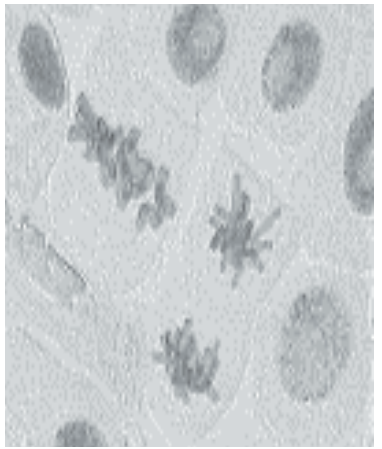

(f)

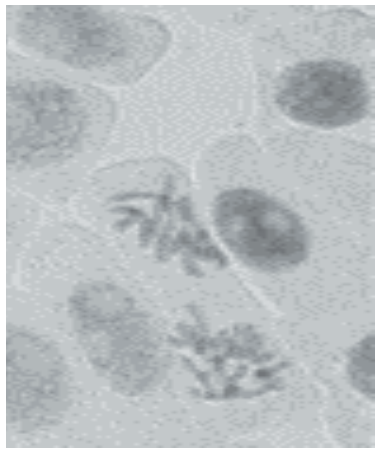

(j)

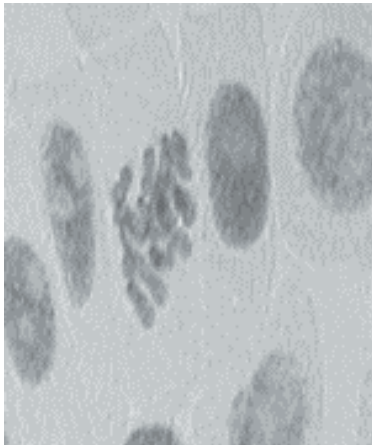

(c)

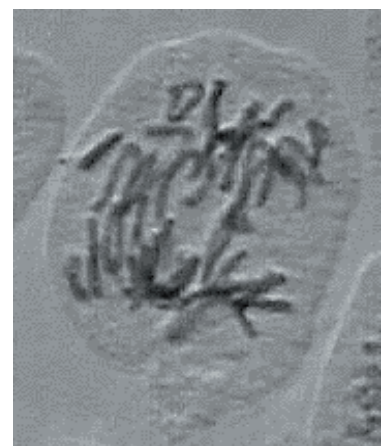

(g)

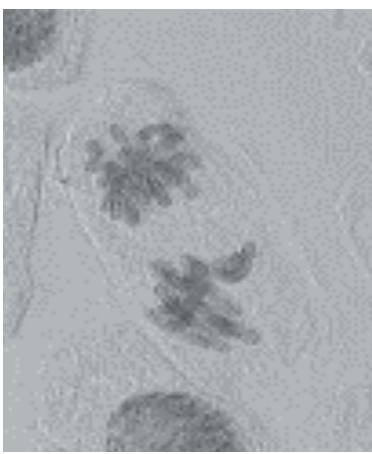

(k)

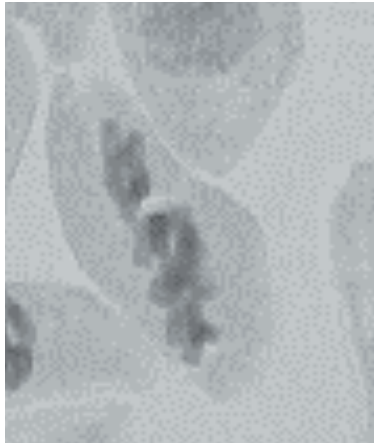

(d)

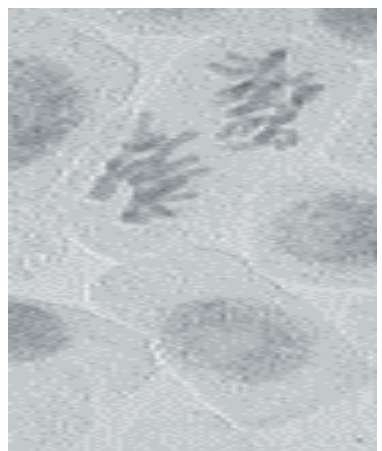

(h)

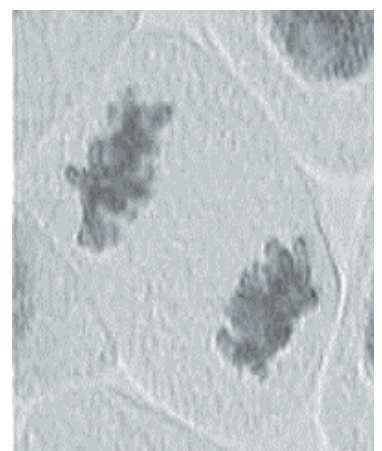

(l)

Figure 2. The most common types of mitotic abnormalities induced in AcR after treatment with different doses of GsEE. a: Disturbed metaphase; b-c: C-metaphase; d: Sticky diagonal metaphase; e: sticky metaphase; f: Sticky metaphase \&anaphase; g: Disturbed anaphase; h-j: disturbed diagonal anaphase; k: sticky disturbed anaphase; 1: Severe sticky anaphase.

\section{DNA fragmentation}

The induction of internucleosomal DNA cleavage in AcR cells was analyzed by agarose gel electrophoresis. GsEE successfully cleaved the genomic DNA of AcR cells and gave a genome-specific fingerprint of DNA fragments (Fig. 4). Agarose gel electrophoresis showed the presence of the ladder pattern of degraded DNA. GsEE produced multiple-bands profiles. Therefore, Fig.
4 verified that the induction of ladder pattern was dose dependent.

\section{Endonuclease activity}

Nuclease activity assay was carried out using nuclease extracts from AcR cells treated with GsEE for 6 and 12h. A dose and time dependent increase in nuclease activity was found. Table 3 revealed that the nuclease 


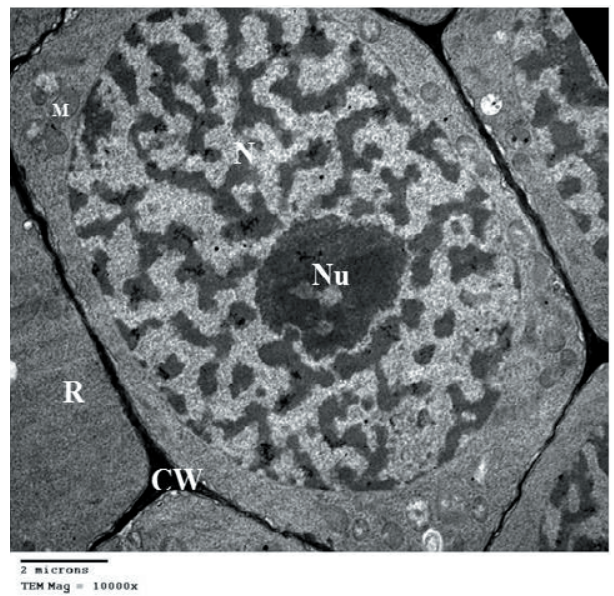

(a)

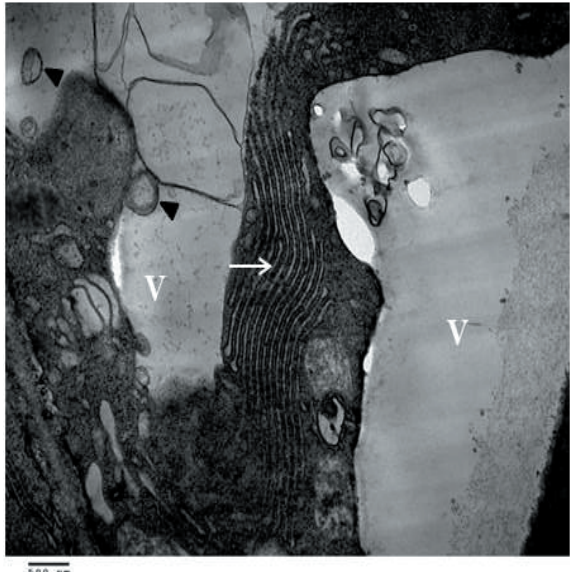

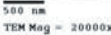

(b)

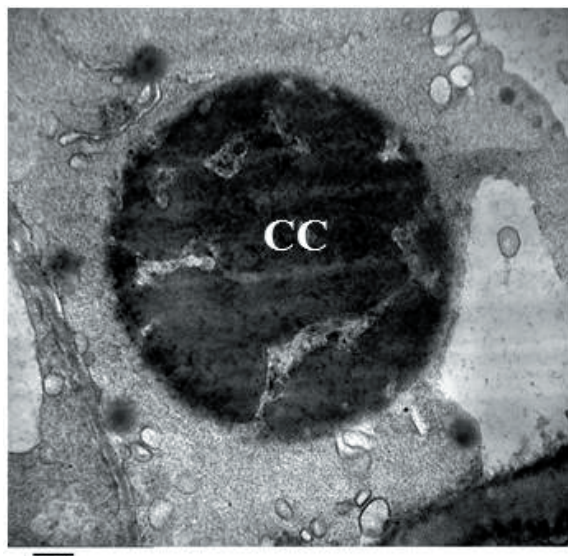

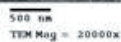

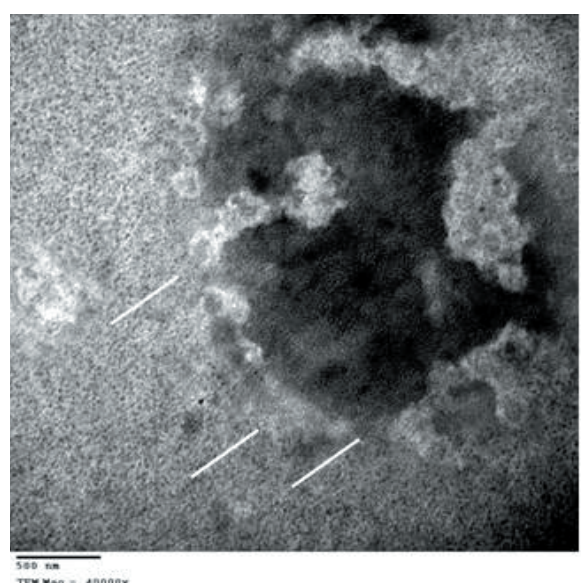

(c)

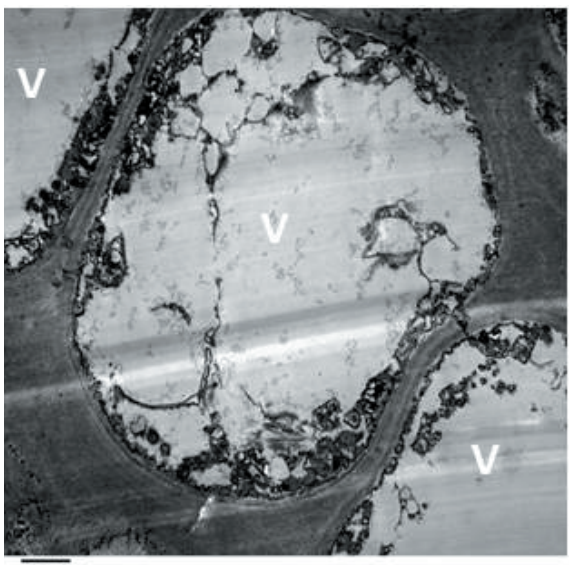

(e)

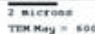

(d)

Figure 3. Electron micrographs of control and treated AcR with GsEE. (a): Electron micrograph of control A. cepa root tip showing large nucleus $(\mathrm{N})$, nucleolus $(\mathrm{Nu})$, cell wall $(\mathrm{CW})$, mitochondrion $(\mathrm{M})$ and free ribosomes $(\mathrm{R})$; (b): Formation of dilated endoplasmic reticulum (arrow) and the presence of organelle inside the vacuole (arrowhead); (c): Disintegration of nuclear envelope (line); (d): Formation of clotting chromatin (CC); (e): Final stage of cell death with the unusual shrinkage of the cell contents, expanding of vacuolar system (V) and the cytoplasm was observed only around the periphery of the cell. 


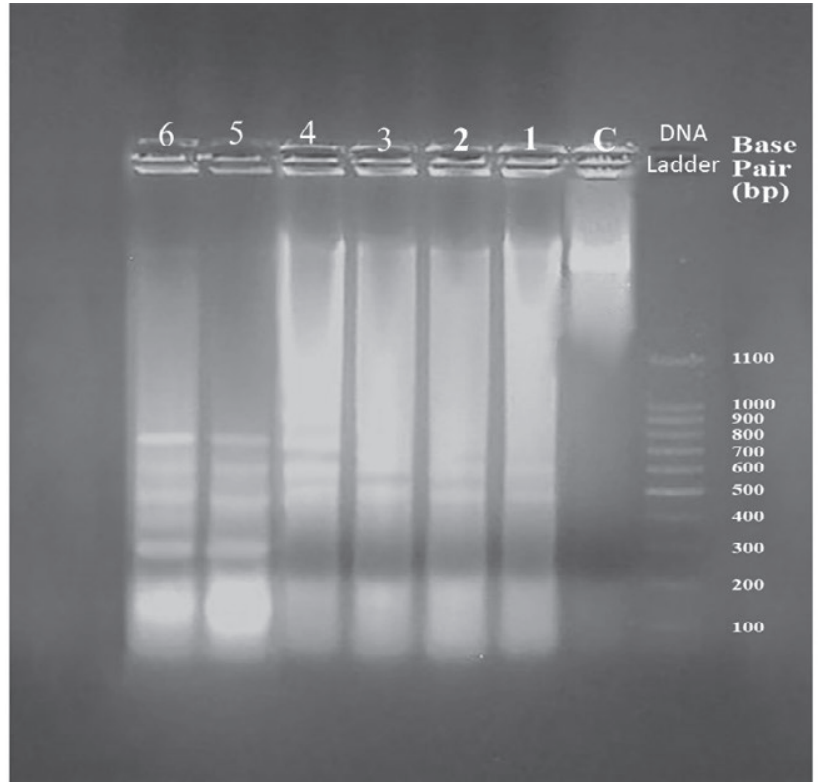

Figure 4. Induction of DNA fragmentation in AcR cells after treatment with different doses of GsEE. C: control; 1:AcR treated with $0.1 \%$ GsEE for $6 \mathrm{~h} ; 2$ : AcR treated with $0.1 \%$ GsEE for $12 \mathrm{~h}$; 3 : AcR treated with $0.3 \%$ GsEE for 6 h; 4 : AcR treated with $0.3 \%$ GsEE for 12h; 5: AcR treated with $0.5 \%$ GsEE for $6 \mathrm{~h} ; 6$ : AcR treated with $0.5 \%$ GsEE for $12 \mathrm{~h}$.

Table 3. Nuclease enzyme activity (units $\mathrm{g}^{-1}$ fresh weight) in AcR cells during the induction of programmed cell death by GsEE.

\begin{tabular}{lcccc}
\hline $\begin{array}{l}\text { Time/ } \\
\text { Concentration }\end{array}$ & Control & $0.1 \%$ & $0.3 \%$ & $0.5 \%$ \\
\hline $6 \mathrm{~h}$ & $1.72 \pm 0.18$ & $4.15^{*} \pm 0.27$ & $7.29^{* *} \pm 1.16$ & $10.23^{* *} \pm 0.11$ \\
$12 \mathrm{~h}$ & $1.75 \pm 0.09$ & $5.13^{* *} \pm 0.14$ & $11.61^{* *} \pm 0.31$ & $16.83^{* *} \pm 0.23$ \\
\hline
\end{tabular}

${ }^{\star}$ Statistically significant at $P \leq 0.05$

${ }^{*}$ Statistically significant at $P \leq 0.01$

activity increment was highly significant as compared with their corresponding control and their results were treatment dependent. The nuclease activity increased more than four folds of the control reaching 4.15 units $\mathrm{g}^{-1}$ fresh weight after $6 \mathrm{~h}$ exposure to $0.1 \%$ of GsEE while $12 \mathrm{~h}$ exposure to $0.5 \%$ has increased the nuclease activity more than sixteen folds reaching 16.83 units $\mathrm{g}^{-1}$ fresh weights.

Protein electrophoresis of A. cepa root

The alteration in the protein banding profile of AcR treated with GsEE was recorded in Table 4 and Fig. 5. The total number of bands ranged from 7 to 9 bands.

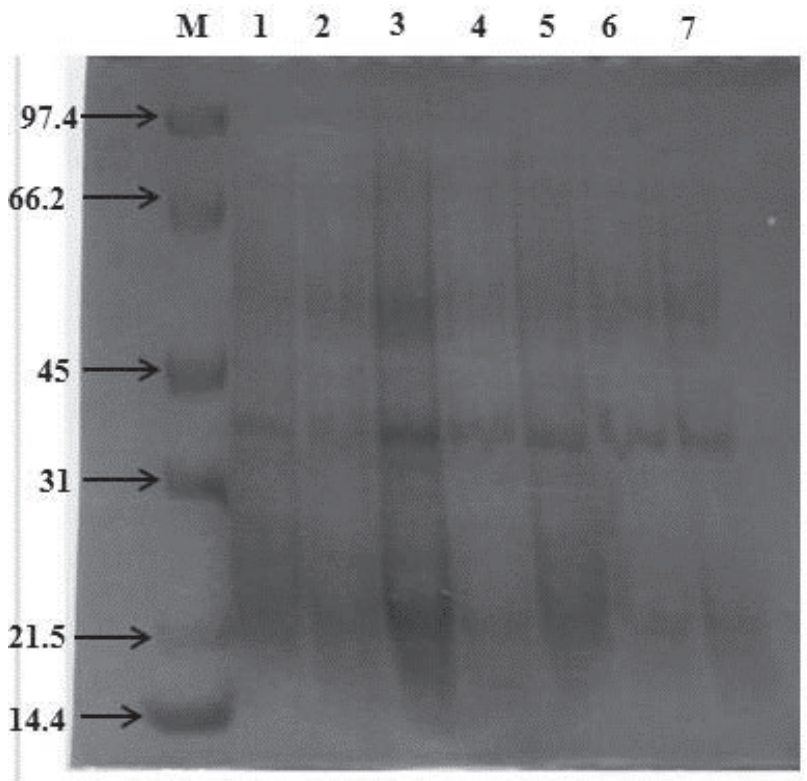

Figure 5. Protein banding pattern of AcR cells after treatment with GsEE. M: marker; 1: control; 2:AcR treated with $0.1 \%$ GsEE for $6 \mathrm{~h}$; 3: AcR treated with $0.1 \%$ GsEE for $12 \mathrm{~h} ; 4$ : AcR treated with $0.3 \%$ GsEE for 6h; 5: AcR treated with $0.3 \%$ GsEE for 12h; 6: AcR treated with $0.5 \%$ GsEE for $6 \mathrm{~h}$; 7 : AcR treated with $0.5 \%$ GsEE for $12 \mathrm{~h}$.

Table 4. Effect of GsEE on protein banding pattern of AcR cells.

\begin{tabular}{|c|c|c|c|c|c|c|c|c|c|}
\hline \multirow{2}{*}{ Band No. } & \multirow{2}{*}{$\begin{array}{c}\text { Mol.Wt. } \\
\text { KDa }\end{array}$} & \multirow{2}{*}{ Marker } & \multirow{2}{*}{ Control } & \multicolumn{2}{|c|}{$0.1 \%$} & \multicolumn{2}{|c|}{$0.3 \%$} & \multicolumn{2}{|c|}{$0.5 \%$} \\
\hline & & & & $6 \mathrm{~h}$ & $12 \mathrm{~h}$ & $6 \mathrm{~h}$ & $12 \mathrm{~h}$ & $6 \mathrm{~h}$ & $12 \mathrm{~h}$ \\
\hline 1 & 97.40 & + & - & - & - & - & - & + & - \\
\hline 2 & 88.23 & & + & + & + & - & - & - & - \\
\hline 3 & 78.64 & & + & - & - & - & - & - & - \\
\hline 4 & 66.20 & + & + & - & + & - & - & - & - \\
\hline 5 & 62.80 & & - & - & - & + & + & - & + \\
\hline 6 & 57.61 & & + & + & + & - & - & + & - \\
\hline 7 & 51.70 & & - & + & + & + & + & + & + \\
\hline 8 & 47.45 & & - & + & + & - & + & - & - \\
\hline 9 & 45.00 & + & - & - & - & + & + & + & - \\
\hline 10 & 40.21 & & + & + & + & - & + & + & + \\
\hline 11 & 35.51 & & - & + & + & + & + & + & - \\
\hline 12 & 31.00 & + & - & - & - & - & + & - & + \\
\hline 13 & 29.00 & & - & + & + & + & + & + & + \\
\hline 14 & 27.07 & & + & - & - & + & - & - & + \\
\hline 15 & 21.50 & + & - & + & + & - & + & + & + \\
\hline 16 & 19.72 & & + & + & + & - & - & + & + \\
\hline 17 & 18.23 & & - & - & - & + & + & + & + \\
\hline 18 & 14.40 & + & - & - & - & - & - & - & - \\
\hline Sum & & & 7 & 9 & 10 & 7 & 10 & 9 & 9 \\
\hline
\end{tabular}

+ present band

- Absent band 
Table 5. High performance liquid chromatography fingerprint of GsEE.

\begin{tabular}{lccc}
\hline Peak no. & Compound & $\begin{array}{c}\text { Ret. Time } \\
{[\mathrm{min}]}\end{array}$ & $\begin{array}{c}\text { Conc. } \\
{[\mathrm{mg} / \mathrm{g}]}\end{array}$ \\
\hline 1 & Gallic acid & 3.135 & 7.92 \\
2 & Chlorogenic acid & 3.502 & 9.13 \\
3 & Catechin & 3.785 & 5.05 \\
4 & Caffeine & 4.046 & 0.38 \\
5 & Caffeic acid & 4.924 & 1.75 \\
6 & Syringic acid & 5.360 & 0.86 \\
7 & Rutin & 5.650 & 3.20 \\
8 & Coumaric acid & 7.667 & 0.30 \\
9 & Vanillin & 8.121 & 0.72 \\
10 & Ferulic acid & 8.774 & 0.17 \\
11 & Naringenin & 9.439 & 2.65 \\
12 & Propyl Gallate & 10.414 & 0.64 \\
13 & 4 .7-DihydroxyisoFlavone & 10.519 & 0.77 \\
14 & Quercetin & 10.704 & 3.41 \\
15 & Cinnamic acid & 11.291 & 1.79 \\
\hline
\end{tabular}

The table contains the most abundant identified compounds in retention time order.

The new bands induced in the treated samples were 11 . Most of these bands were with low molecular weight. Treatment with GsEE caused the completely disappearance of protein band with molecular weight of 78.64 $\mathrm{KDa}$, while some bands were disappeared in some treatments only (Table 4).

High performance liquid chromatography (HPLC) fingerprint

Qualitative phytochemical analysis of GsEE was performed by high performance liquid chromatography to determine the biologically active compounds. A total of 15 phytochemicals; ten phenolic acids: gallic acid, chlorogenic acid, catechin, caffeic acid, syringic acid, coumaric acid, vanillin, ferulic acid, propyl gallate, cinnamic acid, four flavonoids: rutin, naringenin, 4 .7-dihydroxyisoflavone, quercetin, and one alkaloid: caffeine was identified. Table 5 shows the abundant identified compounds.

\section{DISCUSSION}

Herbal drugs, including plants, herbal complexes, and herbal products were used thousand years before era of modern drugs. Herbal plants are used all over the world in different methods both in allopathic and traditional systems (Pal and Shukla 2003; Smith-Hall et al. 2012). Based on ethnopharmacological approaches, Revival of drugs with herbal origin specially to treat cancer and immunologic and CNS diseases is highly considerable.

There are also several studies investigating the antiproliferative effects of Galium species on various cancer types. Amirghofran et al. (2006b) reported that G. mite extract exhibited cytotoxic effects against human leukemia cells. Moreover, anti-cancer effect of G. verum aqueous extract was investigated on drug-sensitive and -resistant laryngeal carcinoma cell lines. G. verum was found to be cytotoxic against all tested laryngeal carcinoma cell lines (Schmidt et al. 2014a). In additional study by Schmidt et al. (2014b), sublethal doses of $G$. verum aqueous extract acted as strong inhibitor on the motility of human head and neck cancer cell lines also, the fractional extract of petroleum ether had promising cytotoxic effects on colon cancer HT29 (Pashapour et al. 2020). Furthermore, Aslantürk et al. (2017) proved that G. aparine ethyl acetate and methanol extracts have cytotoxic and apoptotic inducing effect on MCF-7 and Caco-2 cancer cells.

In this study, effect of GsEE on the viability of MCF7 and BHK21 was assessed by SRB method. After $48 \mathrm{~h}$. incubation, GsEE arrested cell proliferation of both MCF-7 at $35 \mu \mathrm{g} / \mathrm{ml}$ and BHK21 at $39.5 \mu \mathrm{g} / \mathrm{ml}$ in a concentration dependent pattern. The American National Cancer Institute (NCI) guidelines set the limit of activity for crude extracts at $50 \%$ inhibition $\left(\mathrm{IC}_{50}\right)$ of proliferation of less than $30 \mu \mathrm{g} / \mathrm{ml}$ after exposure time of $72 \mathrm{~h}$. (AbdelHameed et al. 2012), moreover, a crude extract with $\mathrm{IC}_{50}$ less than $20 \mu \mathrm{g} / \mathrm{ml}$ is considered highly cytotoxic (Mahavorasirikul et al. 2010). Regarding this scale, GsEE showed moderate antiproliferative effect against cancer and normal cell after $24 \mathrm{~h}$ of exposure. Accordingly, at this level of investigation, GsEE is considered as having an impact on MCF-7 and BHK21 cell viability that can be explained by different mechanisms rather than causing cell toxicity.

Cancer developed when unusual cell proliferation is triggered. Apoptosis is a well-established self-destruct system which is essential to normal tissue development and homeostasis (Vaux and Korsmeyer 1999). Apoptosis and its related signalling pathways antagonize the progression of tumor growth (Lowe and Lin 2000). Thus, induction of apoptosis is a highly desirable goal for launching cancer control strategy (Reed and Pellecchia 2005).

The current work documented the program cell death process in AcR evoked by $0.1 \%, 0.3 \%$ and $0.5 \%$ of GsEE. Depression in mitotic division is the first sign to 
the induction of cell death. Depression in mitotic index was previously reported by several medicinal plant extracts (Shalini and Velavan 2017; Karaismailoğlu 2017). In present study mitotic indices analysis elucidates a consecutive decrease in mitotic index as reported by Rubeena \& Thoppil (2018). This decrease may be due to DNA damage and/or spindle damage. McCollum et al. (2005) interpreted the decrease in MI after treatment with arsenic trioxide as result of the G2 phase delay. Zhou and Elledge (2000) cleared that the cell-cycle control system can readily detect DNA damage and arrest the cycle at DNA damage checkpoint. This checkpoint prevents and /or delays entry into mitosis by inactivating the $\mathrm{Cdc} 25$ protein phosphatase. Inactivated $\mathrm{Cdc} 25$ protein phosphatase blocks the dephosphorylation and activation of $\mathrm{M}$ phase cyclin dependent kinases ( $\mathrm{M}-\mathrm{Cdk}$ ) (Hanamata et al. 2020). The pervious explanation indicates that GsEE might delay the progression of cell cycle at DNA Damage Checkpoint and inhibit most cells to enter mitosis (M phase). On the other hand, only a few numbers of cells entered mitosis and accumulated or arrested at metaphase stage, these cells might be unable to perform metaphase checkpoint (The Mitotic Checkpoint). That may cause stabilizing activity of mitotic cyclin dependent kinases (M-CdK) all time and preventing cells to exit from mitosis (Tawab et al. 2014). Drugs causing alterations in microtubules prevent alignment of the daughter chromosomes and consequently lead to stop of mitosis at metaphase and anaphase, which can be finally followed by apoptosis (Safarzadeh et al. 2014; Yanik et al. 2017; Huang et al. 2019).

Metaphase accumulation and induction of spindle disturbance as a common feature of mitotic abnormalities verified the ability of GsEE to abolish and block metaphase to anaphase transition. GsEE might disrupt the equilibrium between polymerization and depolymerization of microtubules. This disruption might target tubulin subunit resulting in failure of cytokinesis (Murata et al. 2013). Besides, the disassembly of mitotic spindle induces a strong signal that greatly prolongs metaphase stage. Therefore, any kinetochore that is not attached to spindle sends out a negative signal to the cell-cycle control system, blocking Cdc20-anaphase, promoting complex (Cdc20-APC) activation, and sisterchromatid separation. Thus, sister-chromatid separation cannot occur until the last kinetochore is attached (Shah and Cleveland 2000). So, the data in the present study confirm that both entry into and exit from mitosis is blocked in treated cells suggesting that GsEE may interfere with the balance between cyclin condensation required for entry into mitosis and exit from mitosis. Pelayo et al. (2003) declared that plant cells unable to perform checkpoint adaptation may instead induce a program of cell death or may simply fail to proliferate, remaining inactive in mitosis depending on the stimulus and features of cell damage.

Ultrastructural analyses illustrate the changes in cytoplasm organelles in relation to nucleus and provide a confirmatory approach to study cell death processes. Adamakis and Eleftheriou (2019) proved the changes in cell ultrastructure of Pisum sativum during the induction of PCD by tungsten. Ultrastructural analysis of AcR treated with $0.1 \%, 0.3 \%$ and $0.5 \%$ GsEE showed that the first detectable events occurred in the cytoplasm is the accumulation of endoplasmic reticulum and its lumen appears dilated as compared with their control. The same finding was also seen in the nucleus of Tillandsia by Brighigna et al. (2006) and proved by Tawab et al. (2014) who elucidated that Allim cepa cells treated with Punica granatum lose contact with their neighbours because of formation of dilated endoplasmic reticulum. This aspect was previously explained by Madeo et al. (1997) who affirmed that the formation of dilated endoplasmic reticulum could be ultimately leading to the programmed cell death in yeast cells. The nucleus displays an irregular shape (pycnosis), with disintegrated nuclear envelope and highly condensed chromatin "clotting chromatin". This nuclear morphology has been described in other forms of plant programmed cell death, including aerenchyma formation in response to hypoxic stress (Gunawardena et al. 2001) and as a response of A. cepa root cells to Punica granatum polyphenol extract by Tawab et al. (2014). Furthermore, the formation of clotting chromatin is a microscopical marker for both apoptotic and nonapoptotic cell death as previously reported by Schwartz (1992). The presence of disintegrated nuclear envelope is resembled to the late stage of animal programmed cell death as previously proved by Gao et al. (2018). The concentration of $0.5 \%$ GsEE were able to increase the size of vacuolar system. Some vacuoles appeared to have cellular debris indicating the presence of autophagic and autolysis processes (Fuzinatto et al. 2007; Papini et al. 2014). Domínguez et al. (2004) reported that the cytoplasm of wheat aleurone cells undergoing PCD showed rapid vacuolation; they thought that vacuolar collapse was indicative of a high hydrolytic activity. Vacuolar collapse has been hypothesized to be a common feature to many forms of plant PCD by Jones (2001) and Tawab et al. (2014). All the previous controlled changes in nuclear structure, cytoplasm, as well as the presence of organelle in complete integrity case in the periphery of the cell are leading to assumption that GsEE is considered as a programmed cell death stimulus which is concurring with Shahid et al. (2017). 
Different concentrations $(0.1 \%, 0.3 \%$ and $0.5 \%)$ of GsEE altered the electrophoretic pattern of AcR protein. The present variations in protein patterns of the treated AcR might be resulted from changes in gene expression, these changes in gene expression occurs at transcriptional or transnational level (Hopkins 1999). Variation in either structural or regulatory genes can induce changes in the protein profile. Herein, most new protein bands were with low molecular weight. Farr and Cohen-Fix (1999) suggested that low molecular weight proteins are believed to be proteolysis enzymes and some of which block the cell cycle progression. Avila and Devarenne (2013) explained the critical role of proteolysis enzymes activity during the induction of programmed cell death in tomato cell culture by chemical treatment. Additionally, large increase in normal proteolytic activity during the senescence of different plants have been documented (Renxian et al, 2013; Karmous et al. 2014). Moreover, the newly induced protein with molecular mass of $21 \mathrm{KDa}$ almost in all treated roots might be required for preventing cells to exit from mitosis because it blocks cell cycle progression at metaphase by determining the substrate specificity of cyclosome/anaphase promoting complex, this conclusion was confirmed by Tawab et al. (2004). Additionally, the presence of protein band with molecular weight of 57.8 might be cyclin dependent kinase inhibitors that have been formerly found in plants and called putative CKIs as reported by Jasinski et al. (2002). In addition, proteins with molecular mass of 18,29,31, 35 and 51KDa could be considered as protein bands for several types of nucleases enzymes that are responsible for DNA degradation as was reported by Yupsanis et al. (2004).

DNA fragments is one of the hallmarks for apoptosis Matilla 2020, subsequently, Detection of DNA fragmentation is currently considered as one of the most frequently used techniques in the study of programmed cell death (Hanna et al. 2013; Shi et al. 2020). Different concentrations $(0.1 \%, 0.3 \%$ and $0.5 \%)$ of GsEE DNA was degraded into multimers of $180 \mathrm{bp}$. This active degradation of genomic DNA during plant programmed cell death has been obtained by several stimuli (Lombardi et al. 2007; Tawab et al. 2014). Ning et al. (2002) suggested that this pattern of DNA fragmentation may be a universal marker of nuclear change during plant programmed cell death. This systematic DNA fragmentation was associated with significant increase in nucleases activity (Sakamoto and Takami 2014; Matilla 2020). Langston et al. (2005) who stated that the nucleic acid catabolism must be catalysed by endonucleases enzymes which are having task of digesting both single-stranded DNA (ssDNA) and double stranded DNA (dsDNA). The increase in nuclease activity signifies the represent- ing of some specific endonucleases with strong activity accumulated in the treated cells (Ning et al. 2002). This explanation can be confirmed by the protein electrophoresis result in the present work as the novel proteins with molecular weights of 29 and 51KDa have been induced in almost all treated AcR suggesting that those new proteins may be $\mathrm{Zn}^{2}+$-dependent nucleases which are responsible for DNA fragmentation (Sodmergen et al. 1991). Other types of nucleases may be existed with molecular weights of 18 and $31 \mathrm{KDa}$ in treated AcR that might cause DNA fragmentation and then cell death as stated by Hosseini and Mulligan (2002) who stated that those nucleases activities were increased in parallel with the increment of DNA fragmentation and cell death.

Plant phenolics which is a well-known as a natural antioxidant induced DNA fragmentation in different human cancer cell lines (HL-60, ML-1, U-937, THP-1) resulting into apoptosis as reported previously by Taraphdar et al. (2001). Moreover, Inone et al. (1994) showed that tannic acid and caffeic acid induced DNA fragmentation in HL-60 cells. Liu et al. (2013) proved the ability of chlorogenic acid to cause G0/G1 arrest and form DNA ladder pattern consequently induce apoptosis in APL HL60 cell line.

The fragmentation of nuclear DNA into specific segments by nuclease enzymes, proved by ladder formation, which confirms a point of no return to the cell to die. This result was considered the final hallmark of cell death (Tawab et al. 2014; Matilla 2020).

Flavonoids are naturally occurring molecules that are abundant in higher plants. There have been reports of flavonoids inducing apoptosis in cancer cells (Wang et al. 1999; Park et al. 2008). HPLC fingerprint of GsEE identified different phenolic and flavonoid compounds with evidenced apoptotic potential such as gallic acid, chlorogenic acid, catechin, caffeic acid, rutin, naringenin, 4'7-dihydroxyisoflavone, quercetin (You and Park 2010; Chen et al. 2013; Bao et al. 2016; Zhang et al. 2016).

In conclusion, the current study could ensure the ability of Galium sinaicum to reprogram the cancer cell (MCF-7) and normal cells (BHK21 and AcR) to enter the death program by arresting cell division, that was clarified by microscopical hallmarks of PCD and finally forming DNA fragmentation with an increment in the endonuclease's enzymes, all the previous features may be attributed to the presence of phenolic and flavonoid compounds.

\section{AUTHOR CONTRIBUTIONS}

Both authors suggested the point of the work and planned the experimental design to achieve this point. 
Both authors supplied the financial support for the work. The writing of the manuscript was done by both authors.

\section{ACKNOWLEDGEMENTS}

Both authors thank Saint Katherine Protectorate members for helping them in collecting tested plant (Galium sinaicum) from Saint Katherine, Egypt and the identification of it. Also, they thank Prof. Dr., Muhammad Raeef Desert Research Center for supporting them Allium cepa.

\section{REFERENCES}

Abdel-Hameed ES, Salih A, Bazaid SA, Shohayeb MM, El-Sayed MM, El-Wakil EA. 2012. Phytochemical studies and evaluation of antioxidant, anticancer and antimicrobial properties of Conocarpus erectus L. growing in Taif, Saudi Arabia. Eur J Med Plants. 2: 93-112.

Adamakis IS, Eleftheriou EP. 2019. Structural Evidence of programmed cell death induction by tungsten in root tip cells of Pisum sativum. Plants. 8: 62; doi. org/10.3390/plants8030062.

Amirghofran Z, Bahmani M, Azadmehr A, Javidnia K. 2006a. Induction of apoptosis in leukemia cell lines by Linum persicum and Euphorbia cheiradenia. J Cancer Res Clin Oncol. 132: 427-432.

Amirghofran Z, Bahmani M, Azadmehr A, Javidnia K. 2006b. Anticancer effects of various Iranian native medicinal plants on human tumor cell lines. Neoplasma. 53: 428-433.

Aslantürk ÖS, Çelik TA, Karabey B, Karabey F. 2017. Active phytochemical detecting, antioxidant, cytotoxic, apoptotic activities of ethyl acetate and methanol extracts of Galium aparine L. British J Pharmaceutal Res. 15(6): 1-16.

Avila J, Devarenne TP. 2013. Ubiquitination of the tomato cell suppressor Adi3 by the Ring E3 ubiquitin ligase AdBil. Biochem Bioph Reas Comm. 430: 119124.

Bao L, Liu F, Guo HB, Li Y, Tan BB, Zhang WX, Peng YH. 2016. Naringenin inhibits proliferation, migration, and invasion as well as induces apoptosis of gastric cancer sgc7901 cell line by downregulation of akt pathway. Tumor Biol. 37: 11365-11374.

Blank A, Mckeon TA. 1989. Single-strand preferring nuclease activity in wheat leaves is increased in senescence and is negatively photoregulated. Proc Nat Aca Sci USA. 86: 3169-3173.
Bradic J, Petkovic A, Tomovic M. 2018. Phytochemical and pharmacological properties of some species of the Genus Galium L. (Galium Verum and Mollugo) Serbian journal of experimental and clinical research. DOI: https://doi.org/10.1515/sjecr-2017-0057.

Brighigna L,Papini A, Milocani E,Vesprini J. 2006. Programmed cell death in the nucellus of Tillandsia. Caryol. 59(40): 334-339.

Chen H, Miao Q, Geng M, Liu J, Hu Y, Tian L, Pan J, Yang Y. 2013. Anti-Tumor effect of rutin on human neuroblastoma cell lines through inducing G2/ M cell cycle arrest and promoting apoptosis. The Sci World J. 2013, Article ID 269165, 8 pages.

Cragg GM, Kingston DG, Newman DJ. 2005. Anticancer agents from natural products. Taylor and Francis Group; Brunner Routledge Psychology Press, London.

Domínguez F, Moreno J, Cejudo F. 2004. A Gibberellininduced nuclease is localized in the nucleus of wheat aleurone cells undergoing programmed cell death. The J Biol Chem. 279 (12): 11530-11536.

Doyle JJ, Doyle JL. 1987. A rapid DNA isolation method for small quantities of fresh tissues. Phytoch Bull Bota Society Amm. 19: 11-15.

El-Gamal AA, Halim AF, Amer MM, Saad HA, Takeya K, Itokawa H. 1999. Flavonol glycosides from Galium sinaicum. Alex J Pharm Sci. 13(1): 41-47.

Farr KA, Cohen-Fix O. 1999. The metaphase to anaphase transition. Euro J Biochem. 263: 1-14.

Fiskesjö G. 1997. sIn: Wang W, Gorsuch JW, Hughes JS. editors. Plants for environmental studies. CRC Lewis Publishers, Boca Raton, New York, pp 308-333.

Fuzinatto VA, Pagliarini MS, Valle CB. 2007. Evidence of programmed cell death during microsporogenesis in an interspecific Brachiaria (Poaceae: Panicoideae: Paniceae) hybrid. Gent Mol Res. 6: 308-315.

Gao Y, Ma Q, Ma YB, Ding L, Xu XL, Wei DF, Wei L, Zhang JW. 2018. Betulinic acid induces apoptosis and ultrastructural changes in MDA-MB-231 breast cancer cells. Ultrastruct Pathol. 42(1): 49-54.

Gîrd C, Costea T, Nencu I, Popescu ML, Duțu LE. 2015. Phytochemical and phytobiological research upon aerial parts and seeds from Peucedanum officinale. Farmacia. 63(2): 247-253.

Glińska S, Gabara B. 2000. Localization of selenium deposits in meristematic cells of Allium sativum L. roots treated with selenium salts. Folia Histochem Cytobiol 38: 143-147.

Gunawardena AHLAN, Pearce DM, Jackson MB, Hawes CR, Evans DE. 2001. Characterization of programmed cell death during aerenchyma formation induced by ethylene or hypoxia in roots of maize (Zea mays L.). Planta. 212: 205-214. 
Güvenalp Z, Kazaz C, Kaya Y, Demirezer LO. 2006a. Phytochemical investigation on Galium humifusum growing in Turkey. Biochem Syst Ecol. 34: 894-889.

Güvenalp Z, Kilic N, Kazaz C, Kaya Y, Demirezer LO. 2006b. Chemical Constituents of Galium tortumense. Turk J Chem. 30: 515-523.

Hanamata S,Kurusu T, Kuchitsu K. 2020. Cell CycleDependence of Autophagic Activity and Inhibition of Autophagosome Formation at M Phase in Tobacco BY-2 Cells. Int J Mol Sci. 21: 9166; doi.org/10.3390/ ijms21239166

Hanna REB, Foster FI, Brennan GP. 2013. Fasciola hepatica: Histological demonstration of apoptosis in the reproductive organs of flukes of triclabendazole-sensitive and triclabendazole-resistant isolates, and in fieldderived flukes from triclabendazole-treated hosts, using in situ hybridisation to visualise endonuclease- generated DNA stand breaks. Vete Paracytol. 191: 240-251.

Harborne JB. 1973. Phytochemicals methods. Chapman and Hill, London.

Hopkins WG. 1999. Introduction to plant physiology. John Wiley, New York, USA pp 298-292.

Hosseini R, Mulligan BJ. 2002. Application of rice (Oryza sativa L.) suspension culture in studying senescence in vitro (I). Single strand preferring nuclease activity. Electro J Biotech. 5: 42-54.

Huang Y,Wang H,Huang X,Wang Q,Wang J, An D, Li J,Wang W,Wua Y. 2019. Maize VKS1 regulates mitosis and cytokinesis during early endosperm development. The Plant Cell. 31: 1238-1256.

Inone I, Suzuki R, Koide T, Sakaguchi N, Ogihara Y,Yabu Y. 1994. Antioxidant, gallic acid, induces apoptosis in HL-60RG cells. Biochem Biophys Res Commun. 204: 898-904.

Jasinski S, Riou-Khamlichi C, Roche O, Perennes C, Bergounioux C, Glab N. 2002. The CDK inhibitor NtKIS1a is involved in plant development, endoreduplication and restores normal development of cyclin D3;1-overexpressing plants. J Cell Sci. 115: 973-982.

Jones AM. 2001. Programmed cell death in development and defense. Plant Physiol. 125: 94-97.

Karaismailoğlu M.C. (2017) Investigation of the antimitotic and antimutagenic effects of methanolic extracts of Pyracantha coccinea. Turk J Life Sci. 2(1): 110-116.

Karmous I, Chaoui A, Jaouani Kh Sheehan D, Ferjani E, Scoccianti V, Crinelli R. 2014. Role of the ubiquitin proteasome pathway and some peptidases during seed germination and copper stress in bean cotyledons. Plant Physiol Biochem. 76: 77-85.

Kaufman PB, Leland J, Warber CS, James A, Harry D, Brielmann L. 1999. Natural products from plants. CRC Press, London pp. 1581-1589.
Laemmli UK. 1970. Cleavage of structural proteins during the assembly of the head of bacteriophage T4. Nat. 227: 680-685.

Langston JB, Bai S, Jones LM. 2005. Increases in DNA fragmentation and induction of a senescence-specific nuclease are delayed during corolla senescence in ethylene insensitive (etr1-1) transgenic petunias. J Exper Bot. 56: 15-23.

Liu Y, Zhou C, Qiu C, LU X, Wang Y. 2013. Chlorogenic acid induced apoptosis and inhibition of proliferation in human acute promyelocytic leukemia HL60 cells. Mol Med Rep. 8: 1106-1110.

Lombardi L, Ceccarelli N, Picciarelli P, Lorenzi R. 2007. DNA degradation during programmed cell death in Phaseolus coccineus suspor. Plant Physiol Biochem. 45(3-4): 221-227.

Lowe S.W. Lin AW. 2000. Apoptosis in cancer. Carcinogen. 21: 485-495.

Madeo F, Fröhlich E, Fröhlich KU. 1997. A yeast mutant showing diagnostic markers of early and late apoptosis. J Cell Biol. 139: 729-734.

Mahavorasirikul W, Viyanant V, Chaijaroenkul W, Itharat, A, Bangchang K. 2010. Cytotoxic activity of Thai medicinal plants against human cholangiocarcinoma, laryngeal and hepatocarcinoma cells in vitro. BMC Complement Altern Med. 10: 55.

Matilla A. 2020. Programmed cell death in seeds: an adaptive mechanism required for life. In: Seed dormancy and germination. IntechOpen, London United Kingdom.

McCollum G, Keng PC, States JC, McCabe MJ. 2005. Arsenite delays progression through each cell cycle phase and induces apoptosis following G2/M arrest in U937 myeloid leukemia cells. J Pharmacol Exp Ther. 313: 877-887.

Murata T, Sano T, Sasabe M, Nonaka Sh, Higashiyama T, Hasezawa S, Machida Y, Hasebe M. 2013. Mechanism of microtubule array expansion in the cytokinetic phragmoplast. Nat Comm. 4: 1967 doi: 10.1038/ ncomms 2967.

Newman DJ, Cragg GM, Snader KM. 2002. Natural products as a source of new drugs over the period. J Nat Prod 66: 1022-1037.

Ning SB, Wang L, Song YC. 2002. Identification of programmed cell death in situ in individual plant cells in vivo using a chromosome preparation technique. J Exp Bot. 53: 651-658.

Pal SK, Shukla Y. 2003. Herbal medicine: current status and the future. Asian Pac J Cancer Prev. 4(4): 281288.

Papini A, Mosti S, Doorn W. 2014. Classical macroautophagy in Lobivia rauschii (Cactaceae) and possible 
plastidial autophagy in Tillandsia albida (Bromeliaceae) tapetum cells. Protopl. 251(3): 719-725.

Park HJ, Kim MJ, Ha E, Chung JH. 2008. Apoptotic effect of hesperidin through caspase 3 activation in human colon cancer cells, SNU-C4. Phytomed. 15: 147-151.

Pashapour S, Heshmati M, Mousavi Z, Esmaeili S. 2020. The cytotoxicity of the chloroform and petroleum ether fractional extracts of Galium verum L. in HepG2 and HT29 cell lines. J Kermanshah Univ Med Sci. doi: 10.5812/jkums.101079.

Pelayo RH, Pincheira J, Gimenez-Abian JF. Clarke DJ, Connsuelo T. 2003. P53-Independent checkpoint controls in a plant cell model. Biol Res. 36: 381-388.

Reddy BS, Wang CX, Samaha H, Lubet, R, Steele, VE, Kelloff GJ, Rao CV. 1997. Chemoprevention of colon carcinogenesis by dietary perillyl alcohol. Cancer Res. 57: 420-425.

Reed JC, Pellecchia M. 2005. Apoptosis-based therapies for hematologic malignancies. Blood 106: 408-418.

Renxian W, Liu Sh, Wang J, Dong Q, Xu L, Rui Q. 2013. Purification, characterization, and identification of a senescence related serine protease in dark-induced senescent wheat leaves. Phytochem. 95: 118-126.

Reynolds E. 1963. The use of lead citrate at a high $\mathrm{pH}$ as an electron-opaque stain in electron microscopy. J Cell Biol. 17: 208-212.

Rubeena M, Thoppil J. 2018. Cytotoxic potential of Cissus quandrangularis on Allium cepa root meristem. Int J Adv Pharmaceut Sci. 10(1): 1-6.

Safarzadeh E, Shotorbani S, Baradaran B. 2014. Herbal medicine as inducers of apoptosis in Cancer Treatment. Adv Pharm Bull. 4(Suppl 1): 421-427.

Sakamoto W, Takami T. 2014. Nucleases in higher plants and their possible involvement in DNA degradation during leaf senescence. J Exper Bot. 65(14): 3835-3843.

Schmidt M, Scholz CJ, Gavril GL, Otto C, Polednik C, Roller J, Hagen R. 2014a. Effect of Galium verum aqueous extract on growth, motility and gene expression in drug-sensitive and-resistant laryngeal carcinoma cell lines. Int J Oncol. 44: 745-760.

Schmidt M, Polednik C, Roller J, Hagen R. 2014b. Galium verum aqueous extract strongly inhibits the motility of head and neck cancer cell lines and protects mucosal keratinocytes against toxic DNA damage. Oncol Rep. 32: 1296-1302.

Schwartz BW. 1992. Insect muscle as a model for programmed cell death. J Neurobiol. 23: 1312-1326.

Shah JV, Cleveland DW. 2000. Waiting for anaphase. Mad2 and the spindle assembly checkpoint. Cell. 103: 997-1000.

Shahid M, Wang J, Gu X, Chen W, Ali T, Gao J, Han D, Yang R, Fanning S, Han B. 2017. Prototheca zop- fii induced ultrastructural features associated with apoptosis in bovine mammary epithelial cells. Front Cell Infect Microbiol. 7: 299; doi.org/10.3389/ fcimb.2017.00299

Shalini R, Velavan S. 2017. Evaluation of antimitotic activity of Aplotaxis auriculata rhizomes using Allium cepa root meristamatic cells. Ind J Appl Res. 7(12): 315-317.

Shi C,Luo P, Zhao P,Sun M. 2020. Detection of embryonic suspensor cell death by whole-mount TUNEL assay in Tobacco. Plants. 9: 1196; doi:10.3390/ plants9091196

Smith-Hall C, Larsen HO, Pouliot M. 2012. People, plants, and health: a conceptual framework for assessing changes in medicinal plant consumption. J Ethnobiol Ethnomed. 8: 43; doi: 10.1186/1746-4269-8-43.

Sodmergen KS, Tano S, Kuroiwa T. 1991. Degradation of chloroplast DNA in second leaves of rice (Oryza sativa) before leaf yellowing. Protopl. 160: 89-98.

Stevenson DE, Hurst RD. 2007. Polyphenolic phytochemicals - just antioxidants or much more? Cell Mol Life Sci. 64: 2900-2916.

Tada Y, Hata S, Takata Y, Nakayashiki, H, Tosa Y, Mayama S. 2001. Induction and signaling of an apoptotic response typified by DNA laddering in the defense response of oats to infection and elicitors. Mol PlantMicrobe Interact. 14: 477-486.

Taraphdar AK, Roy M, Bhattacharya RK. 2001. Natural products as inducers of apoptosis: Implication for cancer therapy and prevention. Cur Sci. 80 (11): 1387-1396.

Tariq A, Sadia S, Pan K, Ullah I, Mussarat S, Sun F, Abiodun OO, Batbaatar A, Li Z, Song D et al. 2017. A systematic review on ethnomedicines of anticancer plants. Phytother Res. 31: 202-264.

Tawab SAF, Adam ZM, Sobieh Sh. 2014. Assessment of Punica granatum L. extract on the mitotic arrest of plant bioassay system. Life Sci J. 11(8): 757-770.

Tawab SAF, Adam ZM, Sobieh Sh. 2004. Suppression of mitotic process associated with metaphase arrest of Allium cepa L. roots using. I. Rosmarinus officinalis L. Water extract. Int J Agri Biol. 6: 690-698.

Vlase L, Mocan A, 1Hanganu D, Benedec D, Gheldiu A, Crișan G. 2014. Comparative study of polyphenolic content, antioxidant and antimicrobial activity of four Galium species (rubiaceae). digest journal of nanomaterials and biostructures 9(3): 1085-1094.

Vaux DL, Korsmeyer SJ. 1999. Cell death in development. Cell. 96: 245-254.

Vichai V, Kirtikara K. 2006. Sulforhodamine B colorimetric assay for cytotoxicity screening. Nat Protoc. 1: 1112-1116. 
Wang IK, Lin-Shiau SY, Lin JK. 1999. Induction of apoptosis by apigenin and related flavonoids through cytochrome $c$ release and activation of caspase- 9 and caspase-3 in leukaemia HL-60 cells. Eur J Cancer. 35: 1517-1525.

Yanık F, Aytürk V, Vardar F. 2017. Programmed cell death evidence in wheat (Triticum aestivum L.) roots induced by aluminum oxide $\left(\mathrm{Al}_{2} \mathrm{O}_{3}\right)$ nanoparticles. Caryol. 70(2): 112-119.

Yang S, Park S, Ahn D, Yang JH, Kim DK. 2011. Antioxidative constituents of the aerial parts of Galium spurium. Biomol Ther 19(3): 336-341.

You BR, Park WH. 2010. Gallic acid-induced lung cancer cell death is related to glutathione depletion as well as reactive oxygen species increase. Toxicol in Vitro. 24: 1356-1362.

Yupsanis T, Symeonidis L, Kalemi T, Moustaka H, Yupsani A. 2004. Purification, properties and specificity of an endonuclease from Agropyron elongatum seedlings. Plant Physiol Biochem. 42: 795-802.

Zhang H, Zhong X, Zhang X, Shang D, Zhou Y, Zhang C. 2016. Enhanced anticancer effect of abt-737 in combination with naringenin on gastric cancer cells. Exp Ther Med. 11: 669-673.

Zhou BB, Elledge SJ. 2000. The DNA damage response. Putting checkpoints in perspective. Nat. 408: 433439. 